\title{
Asymmetric Transfer Hydrogenation of Ketones in Aqueous Solution Catalyzed by Rhodium(III) Complexes with $\mathrm{C}_{2}$-Symmetric Fluorene-Ligands Containing Chiral $(1 R, 2 R)$-Cyclohexane-1,2-diamine
}

\author{
Rubén Montalvo-González, ${ }^{a, b}$ Daniel Chávez, ${ }^{a}$ Gerardo Aguirre, ${ }^{a}$ \\ Miguel Parra-Hake and Ratnasamy Somanathan*,a \\ ${ }^{a}$ Centro de Graduados e Investigación, Instituto Tecnológico de Tijuana, Apartado Postal 1166, \\ Tijuana, B.C. 22500, México \\ ${ }^{b}$ Unidad Académica de Ciencias Químico Biológicas y Farmacéuticas, Universidad Autónoma de \\ Nayarit, Ciudad de la Cultura Amado Nervo, Tepic, Nay. 63155, México
}

\begin{abstract}
Dois ligantes $\mathrm{C}_{2}$-simétricos bis(sulfonamide) contendo o fluoreno-quiral $(1 R, 2 R)$-ciclohexano1,2-diamina foram complexados com $\mathrm{Rh}^{\text {III }}\left(\mathrm{Cp}^{*}\right)$ e usados como catalizador para redução aromática de cetonas. Os alcoois secundários correspondentes foram obtidos com ee 87-100\% e rendimento de $85-99 \%$, sob condições de transferência de hidrogenio assimétrica (THA), usando formato de sodio aquoso como fonte de hidretos. Usando acetofenona, obteve-se ee de $94 \%$ e rendimento de 86-97\%, com uma razão substrato/catalizador de 10.000 .
\end{abstract}

Two $\mathrm{C}_{2}$-symmetric bis(sulfonamide) ligands containing fluorene-chiral $(1 R, 2 R)$-cyclohexane1,2-diamine were complexed to $\mathrm{Rh}^{\mathrm{III}}\left(\mathrm{Cp}^{*}\right)$ and used as catalyst to reduce aromatic ketones. The corresponding chiral secondary alcohols were obtained in $87-100 \%$ ee and $85-99 \%$ yield, under asymmetric transfer hydrogenation (ATH) conditions using aqueous sodium formate as the hydride source. With acetophenone, $94 \%$ ee and $86-97 \%$ yield was achieved with substrate/catalyst (S/C) ratio of 10,000 .

Keywords: bis(sulfonamide) ligands, $\mathrm{Rh}^{\mathrm{III}}\left(\mathrm{Cp}^{*}\right)$ complexes, asymmetric transfer hydrogenation

\section{Introduction}

The demand for enantiomerically pure compounds have been continuously increasing over the last three decades. This demand is due to strict government regulations that require evaluation of all the possible stereoisomers of a compound and commercialization of a chiral product only as a single enantiomer. ${ }^{1}$ Among small chiral molecules, the chiral alcohols occupy an important place in the synthesis of pharmaceuticals, ${ }^{2}$ cosmetic and food, ${ }^{3}$ and agricultural chemicals. ${ }^{4}$ Thus, the catalytic enantioselective reduction of prochiral ketones is one of the most practical ways to obtain pure chiral secondary alcohols. ${ }^{5}$ Noyori's enantioselective reduction of prochiral ketones using molecular hydrogen and chiral Ru-BINAP-amine complex has already found a useful niche in the fine chemicals industry. ${ }^{6}$

However, in spite of the great advances that have been reached in the area of homogeneous asymmetric catalysis,

*e-mail: somanatha@sundown.sdsu.edu only a limited number of catalysts have found application in the industry. This drawback is mainly due to the cost of metals, metal contamination, environmentally unfriendly solvents and disposal problems, turnover number (TON) and turnover frequency (TOF). ${ }^{7}$ Most of the development on the homogeneous asymmetric catalysts has been made from chiral ligands, which have been synthesized based on phosphorus, amines or amino alcohols derivatives, and then coordinated to $\mathrm{Rh}^{\mathrm{III}}$, $\mathrm{Ru}^{\mathrm{II}}$ or $\mathrm{Ir}^{\mathrm{III}}$ metal centres. ${ }^{8}$

Due to the demand of environmentally friendly methods, the search for water soluble catalysts has received much attention in recent years considering its safety, economical and environmentally benign nature compared to most organic solvents. ${ }^{9}$ Recently, a number of asymmetric transfer hydrogenation (ATH) reports have appeared, using heterogenized or water soluble metal complexes, and sodium formate as the hydride source to get enantiopure chiral alcohols from aromatic prochiral ketones. ${ }^{10}$ Addressing this, we have reported a $\mathrm{C}_{2}^{-}$symmetric bis(sulfonamide)cyclohexane-1,2-diamine ligand [(1), Figure 1] complexed 
with $\left[\mathrm{Rh}^{\mathrm{II}} \mathrm{Cl}_{2}\left(\mathrm{Cp}^{*}\right)\right]_{2}$ which gave high enantioselectivities and yields in the ATH of ketones in aqueous sodium formate. ${ }^{10}$ Searching for a better and "greener" catalyst, herein we report the synthesis of two new $\mathrm{C}_{2}$-symmetric ligands ( $\mathbf{2}$ and $\mathbf{3}$ ), in situ formation of the catalysts with $\left[\mathrm{Rh}^{\mathrm{III}} \mathrm{Cl}_{2}\left(\mathrm{Cp}^{*}\right)\right]_{2}$ and their application in the ATH of twelve ketones with aqueous sodium formate. Ligands $\mathbf{2}$ and $\mathbf{3}$ are derived from $(1 R, 2 R)$-cyclohexane-1,2-diamine and also from 9-oxo-9H-fluorene-2,7-disulfonyl dichloride (for 2) and fluorene-2,7-disulfonyl dichloride (for 3) (Figure 1). In comparison to ligand $\mathbf{1}$, it is expected that the fluorene backbone of ligands $\mathbf{2}$ and $\mathbf{3}$ will provide more rigidity to the complexes inhibiting any possible tetradentate-coordination, thereby making a more active complex and also enhancing enantioselectivity, especially with bulky ketones.

\section{Experimental}

All reagents were commercially available and used without further purification. Melting points were determined on a Fisher-Johns melting point apparatus and are uncorrected. Infrared (IR) spectra were measured on a Perkin Elmer FT-IR 1600 spectrometer. NMR were recorded with Varian Nova $500 \mathrm{MHz}$. The spectra were run in $\mathrm{CDCl}_{3}$ with tetramethylsilane (TMS) as internal standard. Mass spectra were obtained on a Hewlett Packard 5989 MS Spectrometer at $70 \mathrm{eV}$ by direct insertion. Rotation was measured with Perkin-Elmer 343 Polarimeter.

\section{General procedure for the preparation of ligands $\mathbf{2}$ and $\mathbf{3}$}

Bis(sulfonamide) ligand $\mathbf{2}$ was prepared following reported methodology ${ }^{12}$ from the corresponding commercially available 9-oxo-9H-fluorene-2,7-disulfonyl dichloride and $(1 R, 2 R)$-cyclohexane-1,2-diamine. Ligand
3 was prepared following reported methodology ${ }^{13}$ from commercially available fluorene, chlorosulfonic acid, phosphorus pentachloride and $(1 R, 2 R)$-cyclohexane-1,2diamine. Spectra and analytical data of all compounds are given below.

(1R,2R)-9-Oxo-9H-fluorene-2,7-disulfonic acid bis-[(2aminocyclohexyl)-amide] (2)

To a stirred solution of L-tartrate salt of $(1 R, 2 R)$ 1,2-diaminocyclohexane $(0.79 \mathrm{~g}, 3 \mathrm{mmol})$ in aqueous $\mathrm{NaOH}$ $\left(2 \mathrm{~mol} \mathrm{~L}^{-1}, 10 \mathrm{~mL}\right)$ was added triethylamine $(1 \mathrm{~mL}, 7.5 \mathrm{mmol})$ and dichloromethane $(50 \mathrm{~mL})$. The mixture was cooled to $0{ }^{\circ} \mathrm{C}$ and a solution of 9-oxo-9H-fluorene-2,7-disulfonyl chloride $(0.38 \mathrm{~g}, 1 \mathrm{mmol})$ in dichloromethane $(30 \mathrm{~mL})$ was added over $30 \mathrm{~min}$. After the addition was complete, the mixture was allowed to warm to room temperature and stirred for $24 \mathrm{~h}$. The resulting reaction mixture was washed with aqueous $\mathrm{HCl}\left(2 \mathrm{~mol} \mathrm{~L}^{-1}, 3 \times 50 \mathrm{~mL}\right)$ and the organic phase was removed. The $\mathrm{HCl}$ wash liquor was collected and adjusted to $\mathrm{pH} c a .9$ by adding $\mathrm{NaOH}$ pellets until a yellow precipitate appeared. The basic aqueous solution was then extracted with dichloromethane $(3 \times 30 \mathrm{~mL})$. The dichloromethane layers were combined, dried over anhydrous $\mathrm{MgSO}_{4}$, filtered and the solvent was removed under reduced pressure to obtain $\mathbf{2}$ as a pale yellow crystalline solid (0.36 g, $72 \%$ yield); mp: decomposes at $280{ }^{\circ} \mathrm{C}$; $[\alpha]_{\mathrm{D}}^{25}=+22^{\circ}(c 0.34, \mathrm{MeOH})$. IR (film) $\mathrm{v}_{\max } / \mathrm{cm}^{-1}: 3291$, 3254, 3092, 2924, 2905, 2358, 2355, 1716, 1609, 1451, 1319, 1149, 1067, 970, 716. ${ }^{1} \mathrm{H}$ NMR (500 MHz, $\left.\mathrm{CDCl}_{3}\right) \delta$ $8.21(\mathrm{~d}, J 1.5 \mathrm{~Hz}, 2 \mathrm{H}), 8.13(\mathrm{dd}, J 7.8,1.5 \mathrm{~Hz}, 2 \mathrm{H}), 7.80(7.8$ $\mathrm{Hz}, 2 \mathrm{H}), 2.78(\mathrm{td}, J 10.6,3.8 \mathrm{~Hz}, 2 \mathrm{H}), 2.39(\mathrm{td}, J 10.9,4.0$ $\mathrm{Hz}, 2 \mathrm{H}), 1.96-1.88$ (m, 4H), 1.70-1.50 (m, 4H), 1.30-1.02 $(\mathrm{m}, 8 \mathrm{H}){ }^{13} \mathrm{C} \mathrm{NMR}\left(500 \mathrm{MHz}, \mathrm{CDCl}_{3}\right) \delta 190.4,145.8,144.2$, 134.8, 133.6, 122.9, 121.8, 61.0, 54.6, 34.6, 32.5, 25.0, 24.6.<smiles>N[C@@H]1CCCC[C@H]1NS(=O)(=O)c1cccc(S(=O)(=O)N[C@@H]2CCCC[C@H]2N)c1</smiles><smiles>N[C@@H]1CCCC[C@@H]1NS(=O)(=O)c1ccc2c(c1)C(=O)c1cc(S(=O)(=O)N[C@@H]3CCCC[C@H]3N)ccc1-2</smiles>

2<smiles>NC1CCCCC1NS(=O)(=O)c1ccc2c(c1)Cc1cc(S(=O)(=O)N[C@H]3CCCC[C@H]3N)ccc1-2</smiles>

3

Figure 1. Bis(sulfonamide) ligands. 
Elemental Anal. for $\mathrm{C}_{25} \mathrm{H}_{32} \mathrm{~N}_{4} \mathrm{O}_{5} \mathrm{~S}_{2}$; Calcd.: C, 56.37\%; H, $6.06 \%$. Found: C, $56.40 \%$; H, 6.10\%.

$(1 R, 2 R)$-9H-Fluorene-2,7-disulfonic acid bis-[(2-aminocyclohexyl)-amide] $(3)^{13}$

To a stirred solution of fluorene $(1.0 \mathrm{~g}, 6.25 \mathrm{mmol})$ in acetic acid $(10 \mathrm{~mL})$, chlorosulfonic acid $(1.9 \mathrm{~g}$, $18.75 \mathrm{mmol}$ ) was added dropwise at $0{ }^{\circ} \mathrm{C}$. The reaction mixture was refluxed for $2 \mathrm{~h}$, cooled and poured into a saturated aqueous solution of $\mathrm{NaCl}(30 \mathrm{~mL})$ containing $\mathrm{NaOH}(0.62 \mathrm{~g}, 15.62 \mathrm{mmol})$ to obtain a yellow precipitate. The precipitate was washed with a saturated solution of $\mathrm{NaCl}(3 \times 30 \mathrm{~mL})$, filtered and dried overnight at $60{ }^{\circ} \mathrm{C}$ to give sodium fluorene-2,7-disulfonate $(1.62 \mathrm{~g}, 4.38 \mathrm{mmol}$, $70 \%)$. This salt was mixed with phosphorus pentachloride $(2.29 \mathrm{~g}, 11 \mathrm{mmol})$ and phosphorus oxichloride $(8.22 \mathrm{~g}$, $53.64 \mathrm{mmol})$. The reaction mixture was refluxed for $6 \mathrm{~h}$ and the phosphorus oxychloride was distilled off. The resulting dry residue was pulverized in a mortar and then treated with water. The precipitate was filtered and washed with water to give $9 \mathrm{H}$-fluorene-2,7-disulfonil chloride $(1.2 \mathrm{~g}, 3.28 \mathrm{mmol}, 75 \%)$ as a light-reddishbrown powder. The procedure to add the trans- $(1 R, 2 R)$ cyclohexane-1,2-diamine to the sulfonyl groups of the $9 \mathrm{H}$-fluorene-2,7-disulfonil chloride and get ligand $\mathbf{3}$, is was identical to that described for $\mathbf{2}$. Yellow crystalline solid, $(0.38 \mathrm{~g}, 69 \%$ yield $)$; $\mathrm{mp}$ decomposes at $285^{\circ} \mathrm{C}$; $[\alpha]_{\mathrm{D}}^{25}=-57^{\circ}\left(c 0.148, \mathrm{CH}_{2} \mathrm{Cl}_{2}\right) .{ }^{1} \mathrm{H} \mathrm{NMR}\left(500 \mathrm{MHz}, \mathrm{CDCl}_{3}\right)$ $\delta 8.12(\mathrm{~d}, J 1.4 \mathrm{~Hz}, 2 \mathrm{H}), 7.98$ (dd, $J$ 8.0, $1.4 \mathrm{~Hz}, 2 \mathrm{H}), 7.95$ $(8.0 \mathrm{~Hz}, 2 \mathrm{H}), 4.06$ (s, 2H), 2.79 (td, J 10.5, $4.0 \mathrm{~Hz}, 2 \mathrm{H})$, $2.37(\mathrm{td}, J 11.0,4.0 \mathrm{~Hz}, 2 \mathrm{H}), 1.95-1.88(\mathrm{~m}, 4 \mathrm{H}), 1.70-1.6$ $(\mathrm{m}, 4 \mathrm{H}), 1.25-1.04(\mathrm{~m}, 8 \mathrm{H}){ }^{13} \mathrm{C} \mathrm{NMR}\left(125.72 \mathrm{MHz}, \mathrm{CDCl}_{3}\right)$ $\delta$ 144.7, 144.0, 140.4, 126.5, 124.1, 121.2, 60.5, 54.9, 37.1,<smiles>CC(=O)c1ccccc1</smiles><smiles>CCC(=O)c1ccccc1</smiles><smiles>CC(=O)c1ccc2ccccc2c1</smiles><smiles>O=C(CCl)c1ccccc1</smiles><smiles>COc1ccc(C(C)=O)cc1</smiles><smiles>CC(=O)c1ccc(F)cc1</smiles>

35.9, 32.8, 24.9 (2C). Elemental Anal. for $\mathrm{C}_{25} \mathrm{H}_{34} \mathrm{~N}_{4} \mathrm{O}_{4} \mathrm{~S}_{2}$; Calcd.: C, $57.89 \%$; H, 6.61\%. Found: C, 57.93\%; H, 6.65\%.

General procedure for the asymmetric transfer hydrogenation of ketones in water

The metal precursor $\left[\mathrm{Rh}^{\mathrm{II}} \mathrm{Cl}_{2}\left(\mathrm{Cp}^{*}\right)\right]_{2}(0.0025 \mathrm{mmol})$ and the chiral ligand $\mathbf{2}$ or $\mathbf{3}(0.0025 \mathrm{mmol})$ were mixed with water $(0.7 \mathrm{~mL})$ and heated in a water bath at $60{ }^{\circ} \mathrm{C}$ for $1 \mathrm{~h}$. Sodium formate (5 equiv. relative to substrate) and the substrate (ratio $\mathrm{S} / \mathrm{C}=100$ as in Table 1; other S/C ratio presented in Table 2) were subsequently added. The reaction mixture was stirred at $40{ }^{\circ} \mathrm{C}$ in air for the time indicated in Table 1 and Table 2 for each individual reaction. The reaction mixture was extracted with $\mathrm{CH}_{2} \mathrm{Cl}_{2}$ $(3 \times 10 \mathrm{~mL})$. The $\mathrm{CH}_{2} \mathrm{Cl}_{2}$ layers were combined, dried over anhydrous $\mathrm{MgSO}_{4}$, filtered and concentrated in vacuo. The residue containing the alcohol was acetylated using acetic anhydride and 4-DMPA (4- $N, N$-dimethylamino pyridine).

\section{Results and Discussion}

Ligands $\mathbf{2}$ and $\mathbf{3}$ complexed with $\mathrm{Rh}^{\mathrm{III}}\left(\mathrm{Cp}^{*}\right)$ were used as catalysts for the ATH to a series aromatic prochiral ketones (Figure 2) in aqueous sodium formate. The results are shown in Table 1.

Rhodium Cp* complexed ligands $\mathbf{2}$ and $\mathbf{3}$ were tested for catalytic activity in the ATH of aromatic ketones under the same conditions used for ligand $1 .{ }^{10}$ In general, complexes 2- $\mathrm{Rh}^{\mathrm{III}}\left(\mathrm{Cp}^{*}\right)$ and $3-\mathrm{Rh}^{\mathrm{III}}\left(\mathrm{Cp}^{*}\right)$ gave better yields and good enantioselectivities in the ATH compared with ligand $\mathbf{1}$ for ketones $\mathbf{b}, \mathbf{d}$ and $\mathbf{e}$.

In order to test the catalytic properties of these complexes on the ATH of bulky ketones, we reduced<smiles>CCC(=O)c1ccccc1</smiles><smiles>O=C1CCCc2ccccc21</smiles><smiles>O=C(CBr)c1ccccc1</smiles><smiles>O=C(CCCl)c1ccccc1</smiles><smiles>CC(=O)c1ccccc1Cl</smiles><smiles>CC(=O)c1ccc(Br)cc1</smiles>

Figure 2. Structures of ketones used in the ATH. 
Table 1. Enantioselective transfer hydrogenation of ketones with chiral ligands 2 and 3 complexed with $\left[\mathrm{Rh}^{\mathrm{II}} \mathrm{Cl}_{2}\left(\mathrm{Cp}^{*}\right)\right]_{2}$ using aqueous sodium formate

\begin{tabular}{|c|c|c|c|c|}
\hline \multirow[t]{2}{*}{ ketone } & \multicolumn{2}{|c|}{$2^{\mathrm{b}}$} & \multicolumn{2}{|c|}{$3^{\mathrm{b}}$} \\
\hline & $e e^{\mathrm{c}}$ & Yield $^{\mathrm{d}}$ & $e e^{\mathrm{c}}$ & Yield $^{\mathrm{d}}$ \\
\hline $\mathbf{a}$ & 95 & > 99 & 94 & $>99$ \\
\hline b & 95 & 98 & 93 & 99 \\
\hline c & 100 & 85 & 100 & 87 \\
\hline d & 100 & 98 & 100 & 98 \\
\hline $\mathbf{e}$ & 97 & 92 & 97 & 95 \\
\hline f & 90 & $>99$ & 92 & $>99$ \\
\hline g & 88 & 89 & 87 & 93 \\
\hline h & 95 & $>99$ & 96 & $>99$ \\
\hline i & 91 & $>99$ & 91 & $>99$ \\
\hline $\mathbf{j}$ & 91 & $>99$ & 90 & $>99$ \\
\hline k & 89 & $>99$ & 89 & $>99$ \\
\hline 1 & 91 & $>99$ & 90 & $>99$ \\
\hline
\end{tabular}

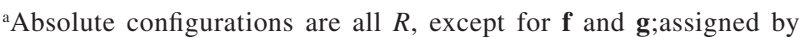
comparing optical rotations with literature values $;{ }^{10}{ }^{\mathrm{b}}$ Ratio substrate/ catalyst $(\mathrm{S} / \mathrm{C})=100 ;{ }^{\mathrm{c}}$ Measured by GC analysis of the acetylated alcohol with chiral capillary column $\beta$-DEX ${ }^{\mathrm{TM}} 120$; ${ }^{\mathrm{d}}$ Reaction conditions: $0.25 \mathrm{~h}$ at $40{ }^{\circ} \mathrm{C}$.

propiophenone (b), valerophenone $(\mathbf{c})$, tetralone $(\mathbf{d})$, 2 '-acetonaphthone (e) and 3-chloropropiophenone (h) to the corresponding alcohols. Results shown on Table 1 indicate good to excellent enantioselctivities and yields.

$\alpha$ - and $\beta$-Haloalcohols are important intermediates in the synthesis of physiologically active molecules. ${ }^{2,3,11}$
Using complexes $2-\mathrm{Rh}^{\mathrm{II}}\left(\mathrm{Cp}^{*}\right)$ and $\mathbf{3}-\mathrm{Rh}^{\mathrm{II}}(\mathrm{Cp} *)$ in the $\mathrm{ATH}$ of 2-chloroacetophenone (f), 2-bromoacetophenone (g) and 3-chloropropiophenone (h), the corresponding chiral alcohols were obtained in $91 \%$ ee, $>99 \%$ yield, $88 \%$ ee, $91 \%$ yield and $95 \% e e,>99 \%$ yield, respectively. Thus, the reduction of halo ketones in aqueous sodium formate provides an excellent and inexpensive synthetic route to synthesize physiologically active 1,2- and 1,3-amino alcohol derivatives.

Substituted aromatic ketones i-l also gave excellent yields and enantioselectivities on the reduction to the corresponding alcohols (Table 1).

In order to study the catalytic activity of the new ligands and the $\mathrm{Rh}$ (III) complexes (TON, TOF) in water/ $\mathrm{HCO}_{2} \mathrm{Na} \mathrm{ATH}$, we reduced acetophenone (a) and 4'-fluoroacetophenone (j) using different catalyst loading, reaction times and reaction temperatures. Results are shown in Table 2, which indicate that the catalyst activity and the enantioselectivities of both complexes $\mathbf{2}-\mathrm{Rh}^{\mathrm{III}}\left(\mathrm{Cp}^{*}\right)$ and $\mathbf{3}-\mathrm{Rh}^{\mathrm{III}}\left(\mathrm{Cp}^{*}\right)$ are similar and constant through $0.25 \mathrm{~h}$ to $5 \mathrm{~h}$. Ligand 3 reached TOF of $3,100 \mathrm{~mol} \mathrm{~mol}^{-1} \mathrm{~h}^{-1}$ in the ATH of acetophenone (a) [entry 4 tested for $0.25 \mathrm{~h}$, at $40{ }^{\circ} \mathrm{C}$ ] and 4,320 ligand $\mathrm{mol} \mathrm{mol}^{-1} \mathrm{~h}^{-1}$ in the ATH of 4'-fluoroacetophenone (j) [entry 8 tested for $0.08 \mathrm{~h}$ and $\left.55^{\circ} \mathrm{C}\right]$.

\section{Conclusions}

We have synthesized two new chiral $\mathrm{C}_{2}$-symmetric ligands with a rigid fluorene ring skeleton with the two cyclohexylamine groups well apart from each other. Both complexes $2-\mathrm{Rh}^{\mathrm{III}}\left(\mathrm{Cp}^{*}\right)$ and $3-\mathrm{Rh}^{\mathrm{III}}\left(\mathrm{Cp}^{*}\right)$ turned out to be very good catalysts in the ATH of aromatic ketones

Table 2. Enantioselective transfer hydrogenation of acetophenone (a) and 4'-fluoroacetophenone (j) with chiral ligands 2 and $\mathbf{3}$ complexed with $\left[\mathrm{Rh}^{\mathrm{III}} \mathrm{Cl}_{2}\left(\mathrm{Cp}^{*}\right)\right]_{2}$ using a mixture of sodium formate/water

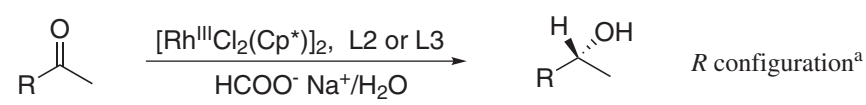

\begin{tabular}{|c|c|c|c|c|c|c|c|}
\hline \multirow[t]{2}{*}{ entry } & \multirow[t]{2}{*}{ ketone } & \multirow[t]{2}{*}{ ratio $(\mathrm{S} / \mathrm{C})$} & \multirow[t]{2}{*}{ time (h) } & \multicolumn{2}{|c|}{ L-2 } & \multicolumn{2}{|c|}{ L-3 } \\
\hline & & & & $e e(\%)^{\mathrm{b}}$ & yield $(\%)^{c}$ & $e e(\%)^{\mathrm{b}}$ & yield $(\%)^{c}$ \\
\hline 1 & a & 100 & 0.08 & 94 & 98 & 94 & 99 \\
\hline 2 & a & 200 & 0.25 & 95 & $>99$ & 94 & $>99$ \\
\hline 3 & a & 1000 & 1 & 95 & $>99$ & 94 & $>99$ \\
\hline 4 & a & 2000 & 2 & 94 & $>99$ & 94 & $>99$ \\
\hline 5 & a & 5000 & 5 & 95 & $>99$ & 94 & 98 \\
\hline 6 & a & 10000 & 12 & 94 & 97 & 94 & 86 \\
\hline 7 & $\mathbf{j}$ & 200 & 0.17 & 91 & $>99$ & 90 & $>99$ \\
\hline 8 & $\mathbf{j}^{\mathrm{d}}$ & 1000 & 0.67 & 91 & $>99$ & 91 & $>99$ \\
\hline
\end{tabular}

${ }^{a}$ Absolute configurations are $R$, assigned by comparing optical rotations with the literature values $;{ }^{10 \mathrm{~b}}$ Measured by GC analysis of the acetylated alcohol with chiral capillary column $\beta$-DEX ${ }^{\mathrm{TM}} 120 ;{ }^{\mathrm{c}}$ at $40{ }^{\circ} \mathrm{C} ;{ }^{\mathrm{d}}$ at $55^{\circ} \mathrm{C}$. 
using aqueous sodium formate as the hydride source, with excellent enantioselectivities, yields and TOF. With these complexes, excellent enantioselectivities and yields on the ATH of bulky ketones were also achieved, making them good candidates for the ATH of other bulky ketones, or to be anchored to a solid phase for the heterogenization of homogeneous catalysts.

The prochiral $\alpha$-chlorine, $\alpha$-bromine and $\beta$-chlorine ketones $\mathbf{f}, \mathbf{g}$ and $\mathbf{h}$ were reduced to the corresponding chiral alcohols in very high yields (> 99\%) and good enantioselectivities (89-91\% ee), providing an alternative synthetic route to obtain 1,2- and 1,3-halo alcohol derivatives.

\section{Acknowledgments}

We gratefully acknowledge support for this project by Consejo Nacional de Ciencia y Tecnología (CONACyT grant 37827-E) and Dirección General de Educación Superior Tecnológica (DGEST grant 310.06-P), and postdoctoral fellowship from CONACyT for R. Montalvo-González.

\section{References}

1. Lin, G-Q.; Li, Y-M.; Chan, A. S.; Principles and Applications of Asymmetric Synthesis, John Wiley \& Sons: New York, 2001; Morrison, J. D.; Asymmetric Synthesis, Academic Press: New York, 1983-1985, vol. 1-5; Noyori, R.; Asymmetric Catalysis in Organic Synthesis, John Wiley \& Sons: New York, 1994.

2. Wang, G.; Liu, X.; Zhao, G.; Tetrahedron:Asymmetry 2005, 16, 1873; Lennon, I. C.; Ramsden, J. A.; Org. Process. Res. Dev. 2005, 9, 110; Cederbaum, F.; Lamberth, C.; Malan, C.; Naud, F.; Spindler, F.; Studer, M.; Blazer, H-U.; Adv. Synth. Catal. 2004, 346, 842; Reilly, M.; Anthony, D. R.; Gallagher, C.; Tetrahedron Lett. 2003, 44, 2927; Okano, K.; Murata, K.; Ikariya, T.; Tetrahedron Lett. 2000, 41, 9277; Hennig, M.; Püntener, K.; Scalone, M.; Tetrahedron:Asymmetry 2000, 11, 1849; Hett, R.; Senanayake, C. H.; Wald, S. A.; Tetrahedron Lett. 1998, 39, 1705; Collins, A. N.; Sheldrake, G. N.; Crosby, J.; Chirality in Industry: The Commercial Manufacture and Applications of Optically Active Compounds, John Wiley \& Sons: Chichester, 1992.

3. Cederbaum, F.; Lamberth, C.; Malan, C.; Naud, F.; Spindler, F.; Studer, M.; Blazer, H-U.; Adv. Synth. Catal. 2004, 346, 842.

4. Hennig, M.; Püntener, K.; Scalone, M.; Tetrahedron:Asymmetry 2000, 11, 1849.

5. Ikariya, T.; Murata, K. ; Noyori, R.; Org. Biomol. Chem. 2006, 4, 393; M. Samec, J. S.; Backvall, J. E.; Andersson, P. G.; Brandt, P.; Chem. Soc. Rev. 2006, 35, 237; Gladiali, S.; Alberico, E.;
Chem. Soc. Rev. 2006, 35, 226; Clapham, S. E.; Hadzovic, A.; Morris, R. H.; Coord. Chem. Rev. 2004, 248, 2201.

6. Ikariya, T.; Blacker, A. J.; Acc. Chem. Res. 2007, 40, 1300; Shimizu, H.; Nagasaki, I.; Matsumura, K.; Sayo, N.; Saito, T.; Acc. Chem. Res. 2007, 40, 1385; Johnson, N. B.; Lennon, I. S.; Moran, P. H.; Ramsden, J. A.; Acc. Chem. Res. 2007, 40, 1291; Blaser, H-U.; Pugin, B.; Spindler, F.; J. Mol. Cat. A: Chem. 2005, 231, 1.

7. Hagen, J.; Industrial Catalysis: A Practical Approach, $2^{\text {nd }}$ ed., Wiley-VCH: Weinheim, Germany, 2006, p. 7; Hamada, T.; Torri, T.; Onishi, T.; Izawa, K.; Ikariya, T.; J. Org. Chem. 2004, 69, 7391; Watanabe, M.; Murata, K.; Ikariya, T.; J. Org. Chem. 2002, 67, 1712; Noyori, R.; Ohkuma, T.; Angew. Chem. Int. Ed. 2001, 40, 40; Matsumura, K.; Hashiguchi, S.; Ikariya, T.; Noyori, R.; J. Am. Chem. Soc. 1997, 119, 8738.

8. Xiao, J.; Wu, X.; Chem. Commun. 2007, 2449.

9. Anastas, P. T.; Warner, J. C.; Green Chemistry: Theory and Practice, Oxford University Press: New York, 2000.

10. Cortez, N. A.; Rodríguez-Apodaca, R.; Aguirre, G.; Parra-Hake, M.; Cole, T.; Somanathan, R.; Tetrahedron Lett. 2006, 47, 8515; Wu, X.; Vinci, D.; Ikariya, T.; Xiao, J.; Chem. Commun. 2005, 4447; Wu, X.; Li, X; Hems, W.; King, F.; Xiao, J.; Chem. Commun. 2004, 1818; Ma, Y.; Liu, H.; Chen, L.; Cui, X.; Zhu, J.; Deng, J.; Org. Lett. 2003, 5, 2103; Liu, S.; Xiao, J.; J. Mol. Cat. A: Chem. 2007, 270, 1; Cortez, N. A.; Aguirre, G.; Parra-Hake, M.; Somanathan, R.; Tetrahedron Lett. 2007, 48, 4335; Cortez, N. A.; Aguirre, G.; Parra-Hake, M.; Cole, T.; Somanathan, R.; Tetrahedron: Asymmetry 2008, 19, 1304; Zhou, Z.; Guo, Y.; Synth. Commun. 2008, 38, 684; Compared with chloro alcohol sample from Aldrich Sigma, rotation (-) for configuration $(R)$, based on rotation (+) the configuration $(S)$ is assigned; Ou, Z.; Wu, J.; Yang, L.; Cen, P.; Korean J. Material Sci. Chem. Eng. 2008, 25, 124.

11. Ohkuma, T.; Tsutsumi, K.; Utsumi, N.; Arai, N.; Noyori, R.; Murata, K.; Org. Lett. 2007, 9, 255; Emami, S.; Foroumadi, A.; Falahati, M.; Lotfali, E.; Rajabalian, S.; Ebrahimi, S.-A.; Farahyar, S.; Shafiee, A.; Bioorg. Med. Chem. 2008, 18, 141; Tanis, S. P.; Evans, B. R.; Nieman, J. A.; Parker, T. T.; Taylor, W. D.; Heasley, S. E.; Herrington, P. M.; Perrault, W. R.; Hohler, R. A.; Dolak, L. A.; Hester, M. R.; Seest, E. P.; Tetrahedron: Asymmetry 2006, 17, 2154.

12. Ng, K.; Somanathan, R.; Walsh, P. J.; Tetrahedron: Asymmetry 2001, 12, 1719.

13. Boer, B.; Meng, H.; Perepichka, D. F.; Zheng, J.; Frank, M. M.; Chabal, Y. J.; Bao, Z.; Langmuir 2003, 19, 4272.

Received: June 15, 2009 Web Release Date: December 3, 2009 